\title{
Proximate Composition of Beef Sausage Processed By Wheat Germ Flour
}

\author{
Elbakheet IS*, Elgasim AE and Algadi MZ
}

Faculty of Agriculture, University of Khartoum, Sudan

\begin{abstract}
Beef sausage was processed by additions of different replacement levels of meat by wheat germ flour (WGF) replacement levels were: $0 \%$ (as control) $10 \%$ and $15 \%$. The processed beef sausage was packaged in foam trays, overwrapped with polyvinyl chloride (PVC) and stored refrigerated at $4^{\circ} \mathrm{C} \pm 1^{\circ} \mathrm{C}$ for up to 7 days. Several variables were determined using subjective and objective measurements, to evaluate the effects of replacement levels and storage periods on the quality attributes of the processed beef sausage. Proximate composition was carried out. The evaluation was conducted immediately after processing, three and seven days post processing day. Results demonstrated that control sample $(0 \%$ replacement level) had the lowest $(p<0.05)$, protein, fat, ash and crude fiber content. There were no significant differences $(p>0.05)$ in fat content, ash content and crude fiber content among the samples from the different replacement levels due to the Storage period. Fifteen percent replacement level sample had the highest $(p<0.05)$ on protein, fat, ash and crude fiber contents. Protein content, fat content, ash content and crude fiber content were increase with the increased of replacement levels. WGF act as binder in beef sausage production and could be a good substitute to others plant binders which are used as meat binder or extenders. It is recommended that use of WGF in $15 \%$ replacement level in manufacturing of comminuted meat products, to enhance their quality characteristics.
\end{abstract}

Keywords: Proximate composition; Sausage; Wheat germ; Polyvinyl chloride

\section{Introduction}

Meat is that edible substance of the many edible food animals, to the trade the term is usually applied to carcass [1]. Sudan has a great meat processing potentiality due to the huge Sudanese livestock resource, according to Pan African Programme for the Control of Epizootics (PACE) Sudanese livestock population for the year 2001 estimated in '000 was 38,325 cattle, 47,034 sheep, 39,952 goats and 3,203 camels. Sausage is one of the old meat products in which fresh comminuted meat are modified by various processing methods to yield desirable organoleptic and keeping properties [2]. Meat and meat products are highly perishable materials, so sanitation and cooling are essentials in handling, marketing and processing of meat. The sanitation in the Sudan, in general is very poor about slaughtering, handling, marketing and processing of meat, except for very few meat plant and slaughter houses.

The demands for the fast meal and readymade food (a sausage is one of the major products used for this meals), is increased in the recent years in worldwide. In Sudan, the strong demands for these types of foods may be due to:

1. Internal migration from rural to urban areas for education, work, etc.

2. Education, governmental and non-governmental universities and good braved schools where usually located in the big cities.

3. Many Sudanese women no longer stay at home for child care or meals cooking but educated and employed in education institutions, factories and other related sectors to improve their social status.

Added to that the external migration, many non-Sudanese labors come from other Asian and African countries to work in Sudan they consumed the fast meals because these meals are international.

Generally, meat products are widely consumed throughout the world; but unfortunately, their cost is high. To reduce this cost there is increasing interest in use of various non-meat proteins especially plant protein. Non-meat protein includes vegetable protein soya beans, cereal and legume protein and are often referred to in the trade name as "meat extenders" or "meat substitutes" [1].

Lin and Zayas [3] reported that increasing cost of animal protein sources has encouraged researchers to study alternative protein sources, to be used in comminuted meat products, because of their lower formulation cost. The objectives of this study are:

i. To evaluate the effects of partial replacement of meat by wheat germ flour on the quality characteristics of beef sausage.

ii. To evaluate the effects of storage periods on the quality characteristics of beef sausage.

\section{Material and Methods}

\section{Materials}

Food materials: Meat loins and round were obtained from Animal Production Research Center Kuku. The beef meat was stored frozen at $-11 \pm 1^{\circ} \mathrm{C}$ in freezer at Regional Training Center for Meat Quality, Grading and Meat Technology, Elkadaro. Wheat germ was obtained from Seen flour mills stored frozen. Spices, salt and sugar were obtained from local market of Khartoum North. The additional fat needed in the formulation was obtained from the local market. Uniform rendered fat free of protein was used.

Chemicals and reagents: Chemicals and reagent used were brought from the central lab stores of Khartoum University, sodium nitrite and ascorbic acid, were obtained from Looly Company, Khartoum.

*Corresponding author: Shawgi Ibrahim Elbakheet, Faculty of Agriculture, University of Khartoum, Sudan, Tel: +249-922544908; E-mail: shawgi1416@gmail.com

Received October 23, 2017; Accepted November 14, 2017; Published November 21, 2017

Citation: Elbakheet IS, Elgasim AE, Algadi MZ (2017) Proximate Composition of Beef Sausage Processed By Wheat Germ Flour. J Food Process Technol 8: 704. doi: $10.4172 / 2157-7110.1000704$

Copyright: @ 2017 Elbakheet IS, et al. This is an open-access article distributed under the terms of the Creative Commons Attribution License, which permits unrestricted use, distribution, and reproduction in any medium, provided the original author and source are credited. 
Citation: Elbakheet IS, Elgasim AE, Algadi MZ (2017) Proximate Composition of Beef Sausage Processed By Wheat Germ Flour. J Food Process Technol 8: 704. doi: 10.4172/2157-7110.1000704

Casings: Cellulose casings $23 \mathrm{~mm}$ in diameter were obtained from Looly Company, Khartoum.

\section{Methods}

\section{Raw materials preparation:}

- Meat preparation: Stored beef was allowed to thaw and sliced then ground through a $0.75 \mathrm{In}$, plate using a meat grinder Ground beef was stored refrigerated at $4^{\circ} \mathrm{C} \pm 1$, for about $20 \mathrm{~h}$, a sample was taken to be analyses for protein fat and moisture content following AOAC method [4] (Table 1).

- Wheat germ preparation: Stored wheat germ was ground, to form wheat germ flour (WGF). Then a sample was taken and analyzed for protein, fat and moisture content, following AOAC method [4] (Table 1).

\section{Calculation for sausage formulation}

The experiment designed to produce sausage with the following specification, protein $15 \%$, fat $20 \%$ moisture, $58.3 \%$ added starch $4.7 \%$, salt $1.5 \%$, and spices $0.5 \%$ (Tables 2 and 3 ). Three batches with three replacements of meat by wheat germ were used every batch weight $2000 \mathrm{~g}$.

Therefore,

Protein required $=\frac{15 \times 2000}{100}=300 \mathrm{~g}$

\begin{tabular}{|c|c|c|c|c|c|c|c|}
\hline Material & $\begin{array}{c}\text { Protein } \\
\%\end{array}$ & Fat \% & $\begin{array}{c}\text { Moisture } \\
\text { content \% }\end{array}$ & $\begin{array}{c}\text { Ash } \\
\%\end{array}$ & $\begin{array}{c}\text { Cured } \\
\text { Fiber \% }\end{array}$ & Carbohydrate & pH \\
\hline $\begin{array}{c}\text { Beef } \\
\text { meat }\end{array}$ & 22.6 & 3.2 & 71 & 0.98 & - & 0.3 & 6.29 \\
\hline $\begin{array}{c}\text { Wheat } \\
\text { germ }\end{array}$ & 27.2 & 9.3 & 10.35 & 2.17 & 2.53 & 48.3 & 6.17 \\
\hline
\end{tabular}

Table 1: Proximate analysis and $\mathrm{pH}$ of beef meat and wheat germ

\begin{tabular}{|c|c|c|}
\hline Components & $\%$ & Weight in grams \\
\hline Protein & 15 & 300 \\
\hline Fat & 20 & 400 \\
\hline Starch & 4.7 & 94 \\
\hline Water & 58.3 & 1160 \\
\hline Salt & 1.5 & 30 \\
\hline Spices & 0.5 & 10 \\
\hline
\end{tabular}

Table 2: Sausage formula

\begin{tabular}{|c|c|c|c|}
\hline \multirow{2}{*}{ Ingredient } & \multicolumn{3}{|c|}{ Replacement level of meat* } \\
\hline & $0 \%$ protein & $10 \%$ protein & $15 \%$ protein \\
\hline Beef meat & 1327.43 & 1194.7 & 1128.32 \\
\hline Wheat germ & - & 110.3 & 165.44 \\
\hline Starch & 94 & 94 & 94100 \\
\hline Fat & 357.52 & 355.15 & 94 \\
\hline Water & 217.53 & 300.34 & 341.3 \\
\hline Salt & 30 & 30 & 30 \\
\hline Sugar & 10 & 10 & 10 \\
\hline Black pepper & 3 & 3 & 3 \\
\hline Nutmeg & 2 & 2 & 2 \\
\hline Cinnamon & 2 & 2 & 2 \\
\hline Garlic & 2 & 2 & 2 \\
\hline Sodium nitrite & 0.13 & 0.12 & 0.11 \\
\hline Vitamin C & 0.62 & 0.55 & 0.52 \\
\hline
\end{tabular}

Table 3: Sausage formulation for all treatments.
Fat required $=\frac{20 \times 2000}{100}=400 \mathrm{~g}$

Water required $=\frac{58.3 \times 2000}{100}=1166 \mathrm{~g}$

Starch required $=\frac{4.7 \times 2000}{100}=94 \mathrm{~g}$

Salt required $=\frac{1.5 \times 200}{100}=10 \mathrm{~g}$

Spices required $=\frac{0.5 \times 200}{100}=10 \mathrm{~g}$

Sodium nitrite $100 \mathrm{ppm}$

Vitamin C $0.466 \mathrm{~g} / \mathrm{kg}$

First replacement level: Wheat germ $0 \%$ so the required protein was $100 \%$ from meat beef. Therefore,

Beef required $=\frac{300 \times 100}{22.6}=1327.43 \mathrm{~g}$

Fat in $1327.43 \mathrm{~g}$ beef $=\frac{3.2 \times 1327.43}{100}=42.48 \mathrm{~g}$

Fat to be added $=400-42.48=357.52$

Moisture in $1327.43 \mathrm{~g}$ beef $=\frac{71 \times 1327.43}{100}=942.47$

Moisture from starch $=6$

Total moisture $=948.47$

Moisture to be added $=1166-948.47=217.53$

Required sodium nitrite $=0.13 \mathrm{~g}$

Required Vitamin $\mathrm{C}=0.62 \mathrm{~g}$

Second replacement level: Wheat germ $10 \%$ so the required protein was $90 \%$ from beef and $10 \%$ from wheat germ. Therefore,

Beef required $=\frac{300 \times 90}{22.6}=1194.7 \mathrm{~g}$

Wheat germ required $=\frac{300 \times 10}{22.6}=110.3 \mathrm{~g}$

Fat in $1194.7 \mathrm{~g}$ beef $=\frac{3.2 \times 1194.7}{100}=38.23 \mathrm{~g}$

Fat in 110.3 wheat germ $=\frac{6 \times 110.3}{100}=6.62 \mathrm{~g}$

Total fat $=44.85 \mathrm{~g}$

Fat to be added $=400-44.85=35515$

Moisture in $1194.7 \mathrm{~g}$ beef $=\frac{71 \times 1194.7}{100}=848.24 \mathrm{~g}$

Moisture in $110.3 \mathrm{~g}$ wheat germ $=\frac{10.35 \times 110.3}{100}=11.42 \mathrm{~g}$

Moisture in $100 \mathrm{~g}$ starch $=6$

Total moisture $=865.66$

Moisture to be added $=1166-865.66=300.34$

Sodium nitrite to be added $=0.12 \mathrm{~g}$

Vitamin $\mathrm{C}$ to be added $=0.56 \mathrm{~g}$ 
Third replacement: Wheat germ $15 \%$ so the required protein in $85 \%$ from beef $15 \%$ from wheat germ. Therefore,

$$
\begin{aligned}
& \text { Beef required }=\frac{300 \times 85}{22.6}=112.32 \mathrm{~g} \\
& \text { Wheat } \text { germ required }=\frac{300 \times 15}{27.2}=165.44 \mathrm{~g} \\
& \text { Fat in } 1128.32 \mathrm{~g} \text { beef }=\frac{3.2 \times 1128.32}{100}=36.11 \mathrm{~g} \\
& \text { Fat in } 165.44 \mathrm{~g} \text { wheat germ }=\frac{6 \times 165.44}{100}=9.95 \mathrm{~g}
\end{aligned}
$$

Fat to be added $=400-46.04=353.96$

Moisture in $1128.32 \mathrm{~g}$ beef $=\frac{71 \times 1128.32}{100}=801.11 \mathrm{~g}$

Moisture in $165.44 \mathrm{~g}$ wheat germ $=\frac{10.35 \times 165.44}{100}=17.12 \mathrm{~g}$

Moisture in $100 \mathrm{~g}$ starch $=6$.

Total moisture $=824.23$

Moisture to be added $=1166-824.23=341.8$

Sodium nitrate $=0.11 \mathrm{~g}$

Vitamin $\mathrm{C}$ to be added $=0.52 \mathrm{~g}$

Sausage preparation: Minced meat, salt, sugar, minced fat, spices, vitamin C, sodium nitrate and half of calculated ice water were introduced to a Hobart Chopper; the Chopper was then started for about $4 \mathrm{~min}$. The added materials were dispersed uniformly. Then the ground wheat germ, starch was added together with the remainder of the calculated water. The entire mass was chopped for about $5 \mathrm{~min}$. then transferred to manual stuffer to be stuffed into cellulose casing of 23 $\mathrm{mm}$ in diameter and linked at lengths of $15 \mathrm{~cm}$. The framed sausage was heated in water at $98^{\circ} \mathrm{C}$ for about $40 \mathrm{~min}$, followed by immediate cooling in ice water, for $15 \mathrm{~min}$. The cooled processed sausage was peeled and packed in foam trays over-wrapped with polyvinyl chloride (PVC) and stored refrigerated for up to 7 days. The WGF replacement levels in beef sausage formulation and processing were performed following the same procedures explained above.

Method of analysis: Sausage were assessed at 0 day (i.e., immediately after processing) after three and seven days post processing.

Moisture content: The moisture content was determined according to the method of AOAC [4]. Calculated as shown below:

Moisture content $\%=\frac{\left(W_{1}-W_{2}\right) \times 100}{W_{1}}$

Where,

$\mathrm{W}_{1}=$ Original weight of sample.

$\mathrm{W}_{2}=$ Weight of sample after drying.

Protein content: The protein content of the samples was determined by the microkjedahl technique according to the AOAC method [4] $0.2 \mathrm{~g}$ of sample was weighed accurately into micro-kjedahl flask, two hundred milligrams of catalyst mixture and $3.5 \mathrm{ml}$ of concentrated sulphuric acid were added, the sample content were heated on an electric heater for $2 \mathrm{~h}$ and cooled, then the contents were placed into the distillation apparatus.

Twenty milliliters of $40 \% \mathrm{NaOH}$ were added the ammonia evolved was received in $10 \mathrm{ml}$ of $2 \%$ boric acid solution. The trapped ammonia was titrated against $\mathrm{HCl}(0.02 \mathrm{~N})$ using universal indicator (methyl red + brooms cresol green), the total nitrogen and protein were calculated using the following formula:

$N \%=\frac{\text { Volume of } H C l \times N \times 14 \times 100}{\text { Weight of sample } \times 1000} P \%=N \% \times 6.25$

Where,

$\mathrm{N} \%=$ crude nitrogen.

$\mathrm{P} \%=$ crude protein .

$\mathrm{N}=$ normality of $\mathrm{HCl}$

$14=$ equivalent weight of nitrogen.

Fat content: Total fat was determined according to the AOAC method [4]. Two grams sample was extracted with petroleum ether BP $60^{\circ} \mathrm{C}$ to $80^{\circ} \mathrm{C}$ for $8 \mathrm{~h}$ in Soxhlet apparatus. The fat content was calculated according to the following equation.

Fat $(\%)=\frac{\left(W_{2}-W_{1}\right)}{\text { Weight of sample }} \times 100$

Where:

$\mathrm{W}_{1}=$ Weight of empty flask.

$\mathrm{W}_{2}=$ Weight of flask with oil.

Ash content: The ash content of sample was measured according to the AOAC method [4] using muffle furnace (model tipoforno ZA No. 18203 Gef Ran 1001), two grams of sample was weighed into porcelain crucible and placed in a temperature controlled furnace controlled furnace at $600^{\circ} \mathrm{C}$ for complete ashing, the crucible with ash was transferred directly to a desiccator, cooled, weight and calculated as percent of original weight of sample.

$$
\text { Ash content }(\%)=\frac{\left(W_{1}-W_{2}\right)}{\text { Sample weight }} \times 100
$$

Where,

$\mathrm{W}_{1}=$ Weight of crucible with ash.

$\mathrm{W}_{2}=$ Weight of empty crucible

Crude fiber: The crude fiber content was carried out by the method of AOAC [4] two grams of dried and defatted sample, were transferred to a $600 \mathrm{ml}$ beaker with a few anti-bombing granules. The sample was digested with $200 \mathrm{ml}$ of $0.255 \mathrm{~N}$ sulphuric acids for exactly $30 \mathrm{~min}$, and the beaker was periodically swirled. The contents were removed and filtered through butcher funnel, and washed with boiling water. The digestion was repeated using $200 \mathrm{ml}$ of $0.313 \mathrm{~N}$ sodium hydroxide for $30 \mathrm{~min}$ and treated similarly as above. After that the fiber was washed with $1 \%$ hydrochloric acid to neutralize the sodium hydroxide and then rinsed with distill water. after the last washing dish, and dried in an oven at $103^{\circ} \mathrm{C}$ for one hour then cooled and weighted. The dried residue was ignited in muffle furnace at $500^{\circ} \mathrm{C}$ overnight, cooled and weighed. The crude fiber was calculated using the following equation.

$C F \%=\frac{\left(W_{1}-W_{2}\right)}{W_{s}} \times 100$

Where:

$\mathrm{CF} \%=$ Crude fiber.

$\mathrm{W}_{\mathrm{S}}=$ Weight of sample.

$\mathrm{W}_{1}=$ Weight of crucible with sample 
$\mathrm{W}_{2}=$ Weight of crucible with ashed sample.

Carbohydrate content: The total carbohydrates were calculated by difference according to AOAC [4] using formula: Total $\mathrm{CHO}=100-$ (Moisture $\%+$ fat $\%+$ protein $\%+$ ash $\%)$.

\section{Statistical analysis}

The data collected from the different treatments was subjected to analysis of variance and whenever appropriate the mean separation procedure of Duncan was employed [5]. The SAS program [6] was used to perform the general linear model (GLM) analysis.

\section{Results and Discussion}

Fifteen percentage replacement level of meat by (WGF) significantly $(p<0.05)$ reduced the moisture content probably due to increase of solid content. There was no significant $(\mathrm{p}>0.05)$ difference between control (0\%) and 10\% replacement levels in moisture content. Moisture content decreased with increase of storage period and this may be due to evaporation of moisture this result as substantiated by the fact that water in muscles exists in three forms: bounds, immobilized and free water, and free water is held by weak surface forces, as water has ability to transform from solid to vapors by sublimation [7]. Storage period within each treatments levels group had no effect $(p>0.05)$ on fat, ash, and crude fiber. Increase of replacement level significantly $(\mathrm{p}<0.05)$ increase protein, fat, ash and crude fiber. That may be due to relatively high protein, fat, ash, and crude fiber of the raw WGF (Table 3) when compared with raw beef. The WGF replacements levels are significantly $(\mathrm{p}<0.05)$ different in carbohydrate content, carbohydrate decreased with the increased of replacement levels, the control sample had relatively the highest $(p<0.05)$ value of carbohydrate content. Such an increase may be due to decrease of fat content which caused by forming of greasy surface and fat caps on the control sample this lead to loss of the fat during peeling and packaging that probably due to absents of binder, carbohydrate content calculated by subtractions, $100-$ (moisture $\%+$ protein $\%+$ fat $\%+$ ash $\%)$, so decrease in any one of moisture, protein, fat and ash will increase carbohydrate content. In 10\% and 15\% WGF replacements levels forming of greasy surface not observed and fat caps rarely observed in $10 \%$ WGF replacements level that may be due to present of WGF which act as binder, Pearson and Gillett [8] showed that plant protein used as binders and extender because they absorb large amount of water and when water added became sticky causing the ground meat to adhere to each other. The later characteristic gives name of binders.

\section{Conclusion}

Protein content, fat content, ash content and crude fiber content were increased with the increased of replacement levels. WGF act as binder in beef sausage production and could be a good substitute to others plant binders which are used as meat binder or extenders. It is recommended that use of WGF in $15 \%$ replacement level in manufacturing of comminuted meat products, to enhance their quality characteristics.

\section{References}

1. Gracey JF (1986) Meat hygiene. Bailliere Tindal, London, UK.

2. FAO (1985) Sausage manufacturing. Food and Agriculture Organization of the United Nations, Rome 72: 102-187.

3. Lin CS, Zayas J (1987) Influence of corn on yield and quality characteristics of comminuted meat products in model systems. J Food Sci 52: 130-138.

4. AOAC (1995) Official method of analysis. Association of Official Analytical Chemists, Washington DC, USA.

5. Steel RG, Torrie JH (1980) Principles and procedures of statistics. MC Grow Hill, New York, USA.

6. SAS (1988) SAS user guide: Release 6.03.

7. Judge MD, Albert ED, Forrest JC, Hedrick MB, Merkel RA (1990) Principle of meat science. Kendall Hunt, Owa, USA.

8. Pearson AM, Gillett TA (1999) Processed meat. Aspen publishers, Gaithers Burg, Maryland, USA. 